\title{
PENGEMBANGAN SISTEM DAN MEKANISME TATA KELOLA KEUANGAN SERTA ANGGARAN ORGANISASI NIRLABA
}

\author{
Widyasari $^{1}$, Syanti $^{2}$, dan Nataherwin ${ }^{3}$ \\ ${ }^{1}$ Jurusan Akuntansi, Universitas Tarumanagara, Jakarta \\ Email:widyasari@fe.untar.ac.id \\ ${ }^{2}$ Jurusan Akuntansi, Universitas Tarumanagara, Jakarta \\ Email:syantid@fe.untar.ac.id \\ ${ }^{3}$ Jurusan Akuntansi, Universitas Tarumanagara, Jakarta \\ Email:nataherwin@fe.untar.ac.id
}

\begin{abstract}
This community service is carried out to fulfill the activities of the Tridharma of Higher Education and to help the community, especially non-profit organizations, regarding the preparation of financial management and mechanisms and to assist them to be more independent in preparing budgets and cash flow. Our partner is a community which is a non-profit association / organization that aims to achieve goals in educational and social. Our partners do not yet have effective cash management, making estimates or projections of cash inflows and outflows periodically, be it a year, semester, quarterly or even monthly. Our partners for every activity that are held never make a budget. Due to the limited knowledge of the organization management, the leaders of the Santo Leopold Community asked us as a team of lecturers to be able to help partners in applying the financial and budget management system. The purpose of this activity is to provide knowledge of financial management to make it more effective and make financial planning, namely the budget. So that the establishment of this organization will continue to grow into a better organization. The specific target of this extension is so that future partners can make budgets and cash flows more independently and and more independently in making good financial governance. This activity will be carried out at the partner's place. This outreach activity is packaged in the form of lectures, tutorials and questions and answers. Lecture material is presented in the form of power points. After that we provide assistance to partners. Evaluation is carried out at the end of this outreach activity.
\end{abstract}

Keywords: budgets, cash flows, non-profit

ABSTRAK
Pengabdian masyarakat ini dilakukan adalah untuk memenuhi kegiatan Tridharma Perguruan Tinggi dan untuk membantu masyarakat khususnya organisasi nirlaba tentang penyusunan mekanisme dan tata kelola keuangan dan mendampingi mereka agar bisa lebih mandiri dalam menyusun anggaran dan arus kas. Mitra kami adalah suatu komunitas dimana adalah sebuah perkumpulan/ organisasi nirlaba yang bertujuan untuk mencapai tujuan dalam hal pendidikan dan sosial. Mitra kami belum memiliki pengelolaan kas yang efektif, dilakukan pembuatan estimasi atau proyeksi arus kas masuk dan keluar secara periodik, baik itu setahun, semester, triwulan bahkan bulanan. Mitra kami untuk setiap kegiatan yang diadakan tidak pernah membuat anggaran. Karena keterbatasan pengetahuan pengurus organisasi, maka pimpinan Komunitas Santo Leopold meminta kami selaku team dosen agar dapat membantu mitra dalam mengaplikasikan sistem tata kelola keuangan serta anggaran. Tujuan kegiatan ini adalah untuk memberikan pengetahuan pengelolaan keuangan agar lebih efektif dan pembuatan planning keuangan yaitu anggaran. Agar kedepannya organisasi ini masih terus bertumbuh menjadi organisasi yang lebih baik. Target khusus penyuluhan ini adalah supaya mitra kedepannya bisa membuat anggaran dan arus kas secara lebih mandiri dan dan lebih mandiri dalam membuat tata kelola keuangan yang baik. Kegiatan ini akan dilakukan di tempat Mitra. Kegiatan penyuluhan ini dikemas dalam bentuk ceramah, tutorial dan tanya jawab. Materi ceramah disajikan dalam bentuk power point. Setelah itu kita memberikan pendampingan ke mitra. Evaluasi dilakukan di akhir kegiatan penyuluhan ini.

Kata Kunci: anggaran, arus kas, nirlaba

\section{PENDAHULUAN}

Perkembangan organisasi nirlaba di Indonesia sangat cukup pesat beberapa tahun terakhir ini, khususnya di bidang keagamaan, kemanusiaan serta advokasi. Organisasi nirlaba (non-profit organisation) adalah organisasi yang tujuan utamanya mendukung suatu isu atau persoalan di masyarakat tanpa mengkomersialkannya atau mencari keuntungan moneter. Contoh organisasi jenis ini adalah gereja, sekolah negeri, rumah sakit dan klinik umum, organisasi politik, bantuan masyarakat, jasa sukarelawan, serikat buruh, asosiasi profesional, lembaga kajian, museum, dsb. (www.wikipedia.org) 
Jika kita perhatikan banyak sekali perbedaan antara organisasi nirlaba dengan organisasi lainnya yang berfokus pada laba. Perbedaan tersebut bisa kita lihat dari sisi kepemilikan, dimana pada organisasi nirlaba tidak diketahui secara jelas siapa pemilik sesungguhnya, apakah anggota atau donatur. Organisasi nirlaba biasanya membutuhkan sumber pendanaan dari para donatur. Sedangkan organisasi laba mempunyai sumber pendanaan yang jelas dari setiap keuntungan usahanya dan para pemilik memperoleh keuntungan dari hasil usaha organisasinya. Juga dari tanggung jawab pengelolaan organisasi laba yang dipegang oleh seorang Direktur.

Lembaga atau organisasi nirlaba merupakan suatu lembaga atau kumpulan dari beberapa individu yang memiliki tujuan tertentu dan bekerja sama untuk mencapai tujuan tadi, dalam pelaksanaannya kegiatan yang mereka lakukan tidak berorientasi pada pemupukan laba atau kekayaan semata (Nainggolan, 2005). Pada sekarang ini tanpa kita sadari bahwa dalam lingkungan kehidupan semakin banyak lembaga nirlaba yang mempunyai peranan penting dalam kehidupan bermasyarakat.

Berdasarkan penjelasan di atas dapat disimpulkan bahwa organisasi nirlaba adalah suatu lembaga/ organisasi yang tujuan pencapainya tidak berfokus mendapatkan laba dari hasil usaha atau kegiatannya. Pada umumnya, sumber daya atau dana organisasi nirlaba yang digunakan dalam menjalankan segala kegiatan yang dilakukan berasal dari donatur atau sumbangan atau sponsorship. Tujuan dari organisasi nirlaba yang paling utama adalah untuk membantu masyarakat luas yang tidak mampu khususnya dalam hal ekonomi.

Organisasi non profit adalah suatu alat untuk mencapai tujuan (aktualisasi filosofi) dari kumpulan beberapa orang yaitu anggotanya. Bukan hal yang tidak mungkin kalau diantara lembaga yang satu dengan lembaga yang lain memiliki pandangan hidup yang berbeda, maka kegiatan operasionalisasi juga pasti akan berbeda. Karena filosofi/ tujuan yang dimiliki organisasi nirlaba sangat tergantung dari sejarah organisasi tersebut dan lingkungan tempat organisasi nirlaba itu berada baik itu politik, ekonomi, sosial dan budaya.

Organisasi nirlaba atau non-profit, mempunyai pengelolaan yang berbeda dengan organisasi lain seperti organisasi profit dan pemerintahan. Kriteria pencapaian dari kinerja organisasi nirlaba berdasar pelayanan kepada masyarakat sesuai dengan prinsip kemanusiaannya, tanpa melihat pertimbangan ekonomi semata. Organisasi nirlaba lebih menfokuskan kepasa perubahan dan pembaharuan masyarakat untuk mengurangi kemiskinan, menciptakan kesejahteraan, kesetaraan gender, keadilan, kedamaian dan bebas dari konflik dan kekerasan.

Banyak dari organisasi nirlaba yang tidak dikelola dengan baik karena kesalahan dan kurang pengetahuan dari orang yang mengelolahnya. Hal tersebut dapat berakibat tujuan dari organisasi itu sendiri tidak tercapai dan malah menjebak masyarakat dalam kemiskinan serta kekerasan sosial. Pada dasarnya dalam suatu pengelolaan organisasi nirlaba sangat dibutuhkan kepedulian dan integritas pribadi dari setiap anggota dan pengurusnya, serta diperlukan pemahaman yang komprehensif mengenai teori manajemen yang handal, unggul dan mumpuni yang berdasarkan pada pengalaman yang konkrit sebagai hasil dari proses pembelajaran bersama masyarakat.

Di Indonesia, organisasi nirlaba lebih menekankan pada kualitas program yang dilaksanakan dan cenderung tidak memperhatikan pentingnya sistem pengelolaan keuangan. Indikator akuntabilitas dan transparansi sebuah lembaga terletak pada sistem pengelolaan keuangan yang baik, dimana diperlukan anggota pengurus organisasi nirlaba yang mempunyai pengetahuan mengenai 
pengelolaan keuangan organisasi nirlaba. Pengetahuan, keterampilan dan pengalaman yang cukup sangat diperlukan untuk anggota pengurus organisasi dalam membangun sistem pengelolaan keuangan yang handal.

Pada saat sekarang ini, sebagian besar organisasi nirlaba di Indonesia dalam keadaan kekurangan dana. Perbedaan ini terlihat sangat mencolok dibandingkan dengan organisasi nirlaba yang berasal dari luar negeri. Suatu organisasi tidak bisa berjalan hanya dengan mengandalkan iuran atau kolektivitas dari para anggotanya. Sumber pemasukan lain baik dari donatur, sponsor, penggalangan dana, ataupun sumbangan dapat memberikan pengaruh terhadap kuantitas dan kualitas dari gerak roda organisasi. Sumber pendanaan menjadi suatu hal yang wajib untuk membantu pengelolaan keuangan suatu organisasi.

Ada banyak sekali cara yang bisa digunakan untuk mendapatkan pendanaan. Cara pertama yang sering digunakan adalah dengan melakukan pengumpulan dana secara kolektif dari anggota organisasi baik itu iuran wajib atau sukarela. Jika cara ini dilakukan secara terus menerus maka sangatlah riskan untuk organisasi tersebut, dimana ada anggota yang tidak mau untuk terus menerus menyetor uang dan akan berdampak pada keharmonisan dalam sebuah organisasi.

Cara kedua adalah dengan mencari donatur. Hal ini kelihatan paling mudah dilakukan untuk mendapatkan pendanaan, tetapi kenyataannya dibutuhkan kemampuan persuasif untuk meyakinkan donatur. Untuk cara ketiga adalah dengan membuka kesempatan sponsor. Sponsorship akan menjadikan adanya asas timbal balik antara pendana dan organisasi dimana sama-sama saling menguntungkan.

Dalam organisasi nirlaba banyak yang belum memiliki manajemen pengumpulan dana yang baik untuk jangka panjang yang dikenal dengan fund development. Untuk membangun pendanaan yang bersifat jangka panjang, diperlukan keterlibatan dari pendonor dan volunteer yang menjadi bagian utama, jadi bukan hanya sekedar dana yang menjadi pusat perhatian.

Mitra kami adalah suatu komunitas dimana adalah sebuah perkumpulan/ organisasi nirlaba yang bertujuan untuk mencapai tujuan dalam hal pendidikan dan sosial. Lokasi mitra kami berada di daerah Tangerang. Mitra kami belum memiliki pengelolaan kas yang efektif, serta tidak pernah melakukan pembuatan proyeksi arus kas masuk dan keluar secara periodik, baik itu setahun, semester, triwulan bahkan bulanan. Mitra kami untuk setiap kegiatan yang diadakan tidak pernah membuat anggaran. Maka kami selaku tim dosen akan mengadakan kegiatan pengabdian masyarakat untuk membantu masalah mitra.

Tujuan kegiatan ini adalah untuk memberikan pengetahuan pengelolaan keuangan agar lebih efektif dan pembuatan planning keuangan yaitu anggaran. Agar kedepannya organisasi ini masih terus bertumbuh menjadi organisasi yang lebih baik.

\section{METODE PELAKSANAAN PKM}

Kegiatan ini dilakukan dalam bentuk penyuluhan dan pendampingan. Untuk kegiatan penyuluhan ini dikemas dalam bentuk ceramah, tutorial dan tanya jawab. Materi ceramah disajikan dalam bentuk power point. Sesi tanya jawab disediakan untuk memperjelas materi bahasan di pengelolaan keuangan dan pembuatan anggaran.

Evaluasi dilakukan di akhir kegiatan penyuluhan ini dengan tingkat keberhasilan menjalankan pembuatan anggaran dan penyusunan proyeksi dan laporan arus kas masuk dan arus kas keluar 
secara mandiri. Kegiatan ini akan dinilai berhasil (memberi dampak atau nilai tambah) jika dari mitra sudah mandiri dalam pelaksanaannya.

Untuk kegiatan pendampingan mitra dalam pelaksanaannya dimulai dari tanggal 6 September 2019 sampai dengan 29 November 2019. Untuk kegiatan pendampingan kami dari team dosen secara bergantian melakukan peninjauan dua minggu sekali ke tempat mitra untuk memastikan dalam pelaksanaannya berjalan baik dan bila ada kendala selama periode pendampingan kita dari team dosen dapat memberikan solusi untuk mengatasi masalah tersebut.

\section{Gambar 1}

Model yang Ditransfer kepada Mitra

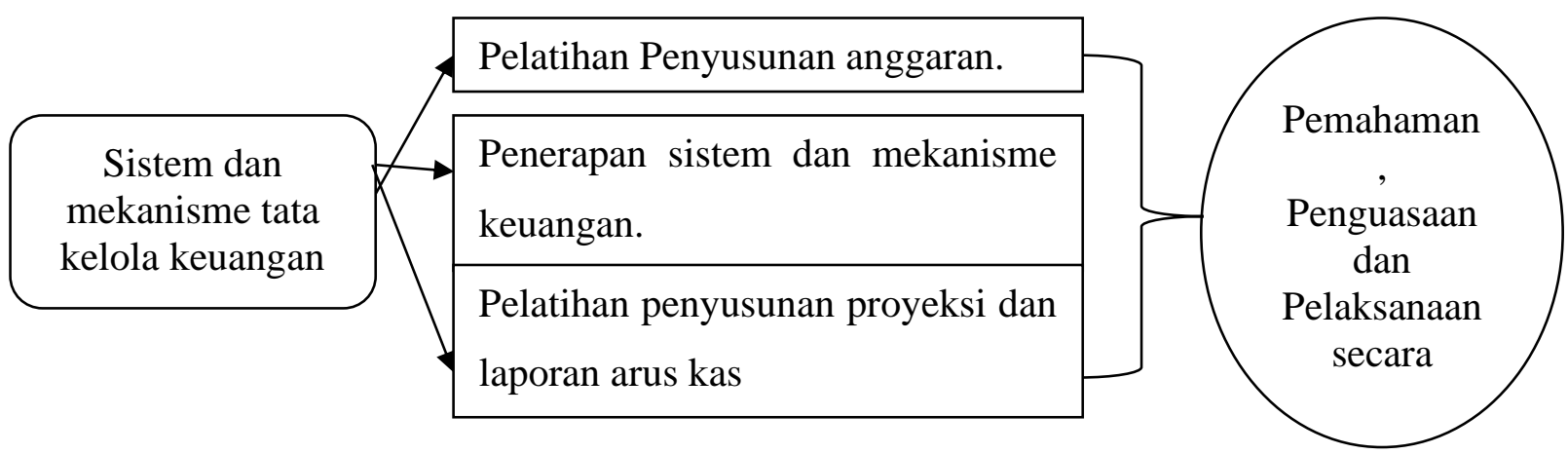

\section{HASIL DAN PEMBAHASAN}

Untuk membuat suatu perencanaan organisasi terutama perencanaan kegiatan dan program kerja dari organisasi nirlaba, maka pembuatan penganggaran merupakan hal yang paling utama. Untuk memulai penyusunan penganggaran, langkah pertama yang harus dimasukkan adalah penentuan visi, misi, dan tujuan strategis organisasi dalam jangka panjang. Setelah itu, baru dijabarkan secara lebih terinci tujuan strategis tersebut ke dalam program dan kegiatan jangka pendek dan menengah serta program kerja tahunan.

Anggaran menurut Nafarin (2009) adalah suatu rencana keuangan periodik yang disusun berdasarkan program yang telah disahkan. Anggaran harus dibuat secara tertulis dan harus dituangkan secara kuantitatif dalam satuan uang untuk setiap kegiatan organisasi yang dibuat untuk jangka waktu tertentu. Anggaran (budget) adalah suatu rencana kegiatan organisasi yang dituangkan dalam satuan keuangan (moneter) dan disusun secara sistematis yang dilakukan dalam jangka waktu yang akan datang, dalam hal ini berlaku untuk seluruh kegiatan. Anggaran mulai dibuat ketika merumuskan perencanaan strategis dalam suatu organisasi dan tahapan ini sangatlah penting untuk dilaksanakan karena anggaran merupakan tindakan perencanaan manajerial dalam memfasilitasi pencapaian tujuan. Perencanaan organisasi yang disusun bisa gagal jika suatu anggaran tidak berorientasi pada tujuan strategis.

Fokus utama dari organisasi nirlaba adalah pencarian sumber dana untuk membiayai seluruh program kegiatannya. Untuk organisasi yang tidak memiliki donatur tetap, pasti memiliki tingkat ketidakpastian yang tinggi dalam mencari sumber dana. Karena ketidakpastian dari sumber pendanaan tersebut, maka pengurus organisasi harus membuat perencanaan yang fleksibel mengenai pengeluaran suatu kegiatan agar dapat menyesuaikan dengan penerimaan yang didapat oleh organisasi tersebut. 
Untuk memastikan kegiatan organisasi berjalan, maka penyediaan kebutuhan uang juga harus sesuai dengan yang dianggarkan, maka dari itu diperlukan suatu pengelolaan uang. Pengelolaan uang dari suatu organisasi dimulai dari proses perencanaan, penerimaan, pengeluaran, pengendalian cashflow, dan serta pelaporan penggunaan uang. Tujuan utama dari pengelolaan uang adalah untuk menjaga ketersediaan dana tunai pada setiap kegiatan dan tidak mengalami kekurangan dana atau cash deficit. Setiap organisasi harus membuat aturan atau prosedur pengelolaan keuangan berdasarkan kesepakatan dari para anggotanya, jadi tidak harus berfokus pada ilmu manajemen keuangan. Hal tersebut dapat membentuk tata kelola suatu organisasi yang menunjukkan kemandirian dalam pengelolaan dana.

Pengelolaan sumber dana tunai dalam suatu organisasi nirlaba hanya berdasarkan kepercayaan dalam mengemban amanat. Oleh sebab itu, maka diperlukanlah orang-orang yang memiliki kredibilitas yang tinggi dalam masyarakat. Jadi banyak orang yang berpikir bahwa keterampilan dan pengetahuan tentang keuangan menjadi tidak penting dan tidak harus sesuai dengan standar keuangan yang berlaku untuk penggunaan, pendanaan hingga pelaporan. Masyarakat hanya ingin mengetahui bahwa sumber dan penggunaan dana tersebut harus dapat dijalankan dan diwujudkan dalam suatu karya nyata. Disini pengurus mempunyai tanggungjawab yang berat karena telah diberikan kepercayaan oleh masyarakat.

Anggaran pada perusahaan atau sektor bisnis dengan anggaran pada organisasi nirlaba memiliki peran dan fungsi yang berbeda. Anggaran pada perusahaan lebih difokuskan pada target penjualan dan biaya produksi, usaha dan pemasaran. Sedangkan anggaran pada organisasi nirlaba merupakan gambaran rencana kegiatan atau program organisasi serta besaran sumber dana yang dibutuhkan dan nantinya akan dibandingkan dengan anggaran penerimaan.

Berikut beberapa tips atau cara pengelolaan kas yang efektif untuk organisasi nirlaba (Nainggolan, 2012). Membuat Anggaran Arus Kas, ini sangat membantu organisasi untuk memastikan bahwa pendanaan dan pengeluaran bisa dilakukan secara efisien; 2. Kerjasama Dalam pengelolaan kas, kerjasama antara pengurus organisasi dan anggota dapat sebagai faktor yang mempengaruhi manajemen kas dan manajemen organisasi secara keseluruhan. Dengan kerjasama yang baik, maka organisasi bisa memberikan hasil yang efektif dengan cara memperhatikan seluruh pihak dalam organisasi berdasarkan kepentingan dan tingkatan prioritas, melalui pertukaran informasi, pendapat dan berbagai pertimbangan dari para anggota, pengurus dan komunitas; 3 . Fleksibilitas dan Kepekaan Dalam pengelolaan kas, fleksibilitas dan kepekaan bisa digunakan untuk menilai mekanisme dan kemampuan agar dapat beradaptasi serta dapat mengantisipasi berbagai perubahan kondisi atau situasi dan dapat menciptakan inovasi serta alternatif jika terjadi perubahan kegiatan atau program kerja. Dengan pengelolaan kas yang fleksibel, maka organisasi nirlaba dapat menekan serta menghindari berbagai risiko atau kemungkinan terjadinya perubahan kondisi keuangan, serta untuk melihat adanya peluang di masa yang akan datang; 4 . Adanya Informasi dan Pengetahuan, hal ini dapat meningkatkan efektivitas dan efisiensi pengelolaan kas. Efektivitas dan efisiensi pengelolaan kas dapat meningkat jika ada informasi dan pengetahuan anggota dan pengurus organisasi yang memadai disertai kecakapan dalam pengelolaan keuangan dan adanya sistem kebijakan yang terintegrasi.

Untuk memberikan gambaran dan langkah yang tepat dalam pengelolaan kas organisasi maka pengurus organisasi membutuhkan informasi dan pengetahuan yang bisa didapat melalui pelatihan, jasa konsultan, pendidikan. Keberhasilan pengelolaan kas tidak terlepas dari adanya perencanaan dan penganggaran yang matang sehingga tujuan dapat tercapai. 
Perencanaan dan pengelolaan keuangan di organisasi nirlaba harus didasarkan pada tujuan strategik organisasi. Biasanya organisasi sudah membuat daftar kegiatan untuk 1 tahun atau setidaknya 6 bulan ke depan. Pembuatan rencana kegiatan dalam jangka panjang ini sangat penting untuk memastikan setiap kegiatan memiliki kesinambungan. Proses perencanaan secara garis besar digambarkan sebagai berikut:

\section{Gambar 2}

\section{Perencanaan Keuangan Organisasi}

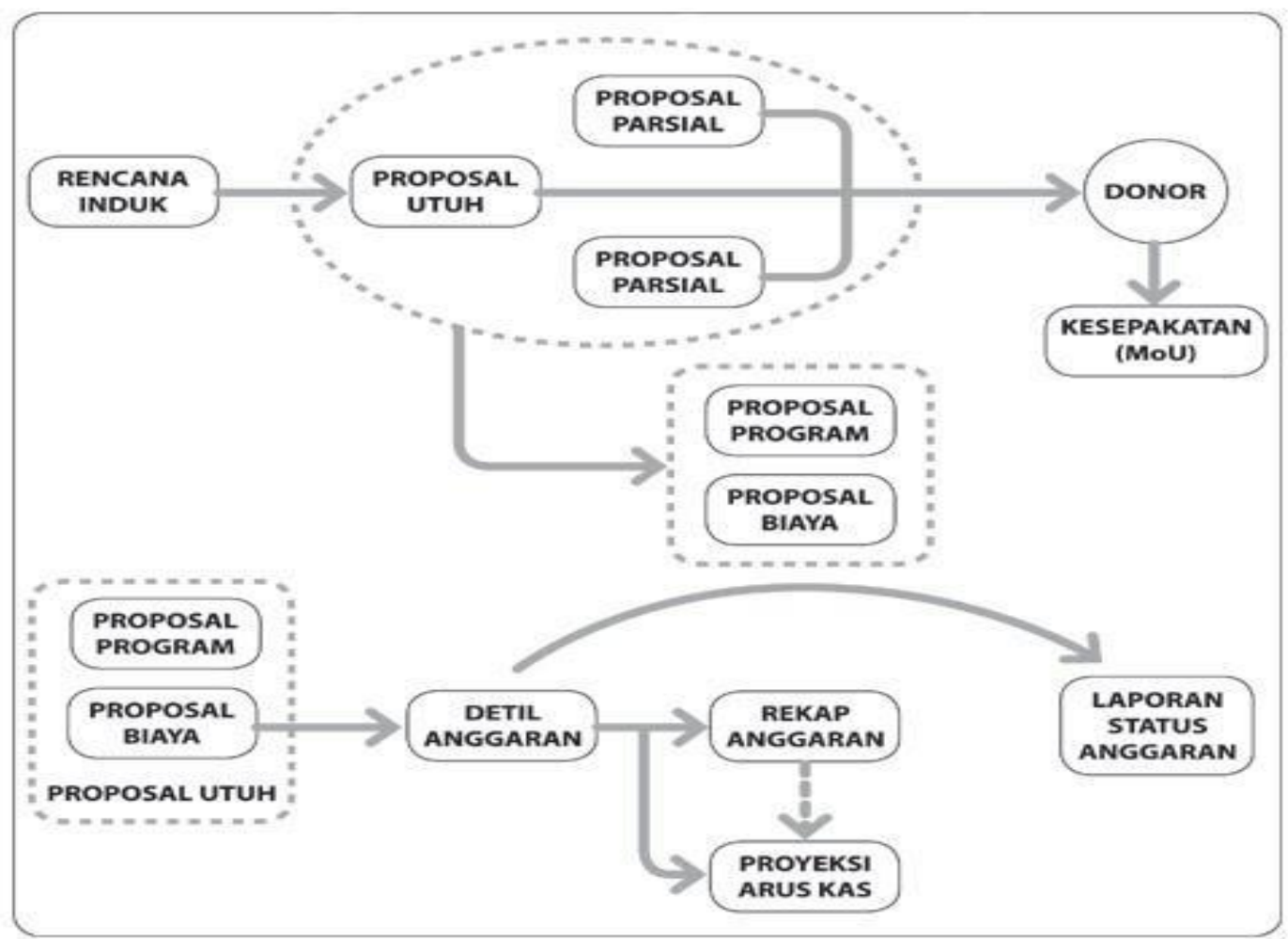

Banyak sekali kegiatan organisasi yang saling tumpang tindih dengan kegiatan lain tanpa memberikan manfaat dan dapat menghabiskan dana serta tidak sesuai dengan tujuan organisasi. Misalnya menyelenggarakan kegiatan sejenis yang sebenarnya sudah dilakukan beberapa bulan kemarin atau dilaksanakan setahun bisa 3-4 kali.

Kas pada organisasi nirlaba biasanya dalam bentuk uang tunai yang biasanya tersimpan di brankas dan dana yang tersimpan di bank. Kas tersebut harus dikelola dengan baik per periode sesuai dengan perencanaan anggaran. Pengelolaan kas ini harus memperhatikan penerimaan dan pengeluaran, sehingga sangatlah penting untuk membuat proyeksi arus kas masuk dan keluar yang dibuat secara periodik, baik itu bulanan, tahunan, semester dan triwulan sesuai dengan kesepakatan.

Manfaat yang bisa kita ambil dari membuat proyeksi arus kas masuk dan keluar, yaitu: 1. bisa sebagai pengingat untuk pengurus organisasi agar tidak terjadi kehabisan kas yang dapat mengganggu terhambatnya kegiatan organisasi. Selain itu pengurus organisasi bisa cepat mengambil keputusan untuk menunda pengeluaran lain yang bukan menjadi prioritas utama atau yang tidak termasuk dalam program kerja; 2. Pengurus organisasi dapat mengetahui jika ada kelebihan dana kas, yang dapat digunakan untuk investasi jangka pendek, atau bisa juga untuk mempercepat pelaksanaan kegiatan yang tertunda. 
Dokumentasi dan pencatatan dalam pengelolaan keuangan organisasi nirlaba sangat diperlukan agar pelaporan menjadi akuntabel dan transparan. Jika setiap pengeluaran dan pemasukan ada dokumentasi dan sistem pencatatan, maka setiap perputaran uang akan dapat diawasi dengan mudah. Pengawasan atas perputaran uang akan membantu balancing di antara pemasukan dan pengeluaran serta membantu tindakan pengawasan terhadap anggota khususnya pengurus organisasi yang ingin melakukan tindak korupsi atau penyalahgunaan uang.

Dengan adanya pengelolaan kas yang transparan dan akuntabel, pengurus organisasi dapat menyajikan informasi kepada penyedia sumber daya (donatur) maupun pada pihak-pihak lain yang berkepentingan dalam pengambilan keputusan untuk pengalokasian sumber daya kepada organisasi nirlaba.Begitu juga dengan penyusunan anggaran yang baik akan menyalurkan dana pada masing-masing kegiatan sesuai dengan kebutuhan dari kegiatan tersebut. Jadi dari pengurus organisasi bisa menentukan mana yang lebih didahulukan dan yang mempunyai skala prioritas.

Hasil dari kegiatan ini mitra bisa memahami sistem dan mekanisme keuangan yang baik untuk organisasi nirlaba, para pengurus organisasi dapat menyusun anggaran tahunan dan anggaran kegiatan, para pengurus organisasi dapat menyusun proyeksi arus kas tahunan, para pengurus organisasi dapat menyusun laporan arus kas tahunan dan kegiatan.

\section{KESIMPULAN DAN SARAN}

Kegiatan pengabdian kepada masyarakat yang dalam hal ini aktivitas penyuluhan dan pendampingan penyusunan anggaran dan arus kas untuk organisasi yang dilaksanakan selama 3 bulan pendampingan. Dari kegiatan ini para anggota organisasi merasa terbantu karena selama ini banyak yang belum pernah menyusun arus kas dan anggaran. Selain itu banyak anggota komunitas yang belum memahami transparansi keuangan dengan penyusunan anggaran.Pelatihan ini diharapkan dan mengelola sumber dana dan penggunaan secara cermat dan efisien sehingga organisasi ini.

Penyuluhan dan pendampingan semacam ini perlu dilakukan secara berkesinambungan agar selain membantu para anggota komunitas dan memberikan motivasi dalam menyempurnakan penyusunan anggaran. Serta memberikan kesempatan kepada anggota untuk memahami keuangan nirlaba.

\section{Ucapan Terima Kasih (Acknowldgement)}

Kami mengucapkan puji dan syukur kepada Tuhan Yang Maha Esa atas segala berkat dan pimpinanNya sehingga kami dapat menyelesaikan pengabdian masyarakat dengan baik dan tepat pada waktunya. Saya dan para team mengucapkan terima kasih kepada Ibu Fie Fie Angelina selaku ketua organisasi yang telah bersedia melakukan kerjasama dan memberikan dukungan dalam kegiatan ini.

\section{REFERENSI}

Wikipedia. (2021, Mei 16). Organisasi nirlaba. https://id.wikipedia.org/wiki/Organisasi_nirlaba Nafarin, M. (2009). Penganggaran perusahaan. Salemba Empat.

Nainggolan, P. (2012). Manajemen keuangan lembaga nirlaba. Yayasan Bina Integrasi Edukasi. 